\title{
Bacillus aerius sp. nov., Bacillus aerophilus sp. nov., Bacillus stratosphericus sp. nov. and Bacillus altitudinis sp. nov., isolated from cryogenic tubes used for collecting air samples from high altitudes
}

Correspondence

S. Shivaji shivas@ccmb.res.in

\author{
S. Shivaji, ${ }^{1}$ P. Chaturvedi, ${ }^{1}$ K. Suresh, ${ }^{1}$ G. S. N. Reddy, ${ }^{1}$ C. B. S. Dutt, ${ }^{2}$ \\ M. Wainwright, ${ }^{3}$ J. V. Narlikar ${ }^{4}$ and P. M. Bhargava ${ }^{5}$ \\ ${ }^{1}$ Centre for Cellular and Molecular Biology, Uppal Road, Hyderabad 500 007, India \\ ${ }^{2}$ Indian Space Research Organization, Antariksha Bhavan, New BEL Road, Bangalore 500 094, \\ India
${ }^{3}$ Department of Molecular Biology and Biotechnology, University of Sheffield, Fifth Court, Western Bank, Sheffield S10 2TN, UK
${ }^{4}$ Inter-University Centre for Astronomy and Astrophysics, Post Bag No. 4, Ganeshkhind, Pune 411 007, India
${ }^{5}$ Anveshna Consultancy Services, Furqan Cottage, Street No. 3, Tarnaka, Hyderabad 500017 , \\ India
}

Four novel bacterial strains were isolated from cryogenic tubes used to collect air samples at altitudes of 24,28 and $41 \mathrm{~km}$. The four strains, $24 \mathrm{~K}^{\top}, 28 \mathrm{~K}^{\top}, 41 \mathrm{KF} 2 \mathrm{a}^{\top}$ and $41 \mathrm{KF}^{2} \mathrm{~b}^{\top}$, were identified as members of the genus Bacillus. Phylogenetic analysis based on 16S rRNA gene sequences indicated that three of the strains, $24 \mathrm{~K}^{\top}, 28 \mathrm{~K}^{\top}$ and $41 \mathrm{KF}^{2} \mathrm{a}^{\top}$, are very similar to one another (>98\% sequence similarity) and show a similarity of $98-99 \%$ with Bacillus licheniformis and $98 \%$ with Bacillus sonorensis. DNA-DNA hybridization studies showed that strains $24 \mathrm{~K}^{\top}$, $28 \mathrm{~K}^{\top}$ and $41 \mathrm{KF}^{2} \mathrm{a}^{\top}$ exhibit $<70 \%$ similarity with each other and with $B$. licheniformis and $B$. sonorensis. Differences in phenotypic and chemotaxonomic characteristics between the novel strains and $B$. licheniformis and $B$. sonorensis further confirmed that these three isolates are representatives of three separate novel species. Strain $41 \mathrm{KF} 2 \mathrm{~b}^{\top}$ showed $100 \% 16 \mathrm{~S}$ rRNA gene sequence similarity to Bacillus pumilus, but differed from its nearest phylogenetic neighbour in a number of phenotypic and chemotaxonomic characteristics and showed only $55 \%$ DNA-DNA relatedness. Therefore, the four isolates represent four novel species for which the names Bacillus aerius sp. nov. (type strain, $24 \mathrm{~K}^{\top}=\mathrm{MTCC} 7303^{\top}=\mathrm{JCM} 13348^{\top}$ ), Bacillus aerophilus sp. nov. (type strain, $28 \mathrm{~K}^{\top}=$ MTCC $7304^{\top}=\mathrm{JCM} 13347^{\top}$ ), Bacillus stratosphericus sp. nov. (type strain, $41 \mathrm{KF} 2 \mathrm{a}^{\top}=\mathrm{MTCC} 7305^{\top}=\mathrm{JCM} 13349^{\top}$ ) and Bacillus altitudinis sp. nov. (type strain, $41 \mathrm{KF} 2 \mathrm{~b}^{\top}=$ MTCC $7306^{\top}=$ JCM $13350^{\top}$ ) are proposed.
Studies on the qualitative and quantitative distribution of micro-organisms in the upper troposphere-stratosphere

Abbreviations: DPG, diphosphatidylglycerol; PE, phosphatidylethanolamine; PG, phosphatidylglycerol; SEM, scanning electron microscopy; UV, ultraviolet.

The GenBank/EMBL/DDBJ accession numbers for the 16S rRNA gene sequences of strains $41 \mathrm{KF}^{2} \mathrm{a}^{\top}, 41 \mathrm{KF}^{2} \mathrm{~b}^{\top}, 24 \mathrm{~K}^{\top}$ and $28 \mathrm{~K}^{\top}$ are AJ831841-AJ831844, respectively.

The UV sensitivity of the four novel strains compared with $B$. licheniformis MTCC $429^{\top}$ and B. pumilus MTCC $1640^{\top}$ is presented in Supplementary Table S1 in IJSEM Online.
(10-85 km altitude) in various parts of the Earth are important as they should help (i) in determining the role of the various atmospheric strata in the transport of microorganisms from one part of the globe to another and (ii) to test the theory that micro-organisms might exist in space (Hoyle \& Wickramasinghe, 1986, 1993, 1999) and form a part of the hundreds of tons of material that enters the atmosphere each day from space (Love \& Brownlee, 1993). It is now well recognized that micro-organisms can survive the harsh conditions of the upper atmosphere and the rigours of outer space (reviewed by Bruch, 1967). Theoretical studies (Bruch, 1967) have indicated that it is also possible for 
micro-organisms of an appropriate size to escape into outer space and thus be transported from one planet to another.

There have been, however, very few published studies on the quantity and nature of micro-organisms in the upper atmosphere (Bruch, 1967; Greene et al., 1964; Lysenko, 1979; Rogers \& Meier, 1936). These studies have used either a meteorological rocket (Lysenko, 1979) or a specially designed direct-flow sampler sent up on a balloon (Greene et al., 1964; Rogers \& Meier, 1936). Both bacteria and fungi have been found at altitudes of up to $85 \mathrm{~km}$ (Lysenko, 1979). In a recent paper, Harris et al. (2001) detected bacteria from stratospheric air samples collected at $41 \mathrm{~km}$ using scanning electron microscopy (SEM) and epifluorescence techniques. Using the same samples, Wainwright et al. (2003) described the presence of two bacterial species (Bacillus simplex and Staphylococcus pasteurii) and a fungus (Engyotontium album). In this paper, a polyphasic taxonomic approach was used to characterize four bacterial strains from cryotubes that were used to collect air at altitudes between 24 and $41 \mathrm{~km}$ during a balloon flight from Hyderabad, India. The four strains, $24 \mathrm{~K}^{\mathrm{T}}, 28 \mathrm{~K}^{\mathrm{T}}, 41 \mathrm{KF} 2 \mathrm{a}^{\mathrm{T}}$ and $41 \mathrm{KF} 2 \mathrm{~b}^{\mathrm{T}}$, represent four novel species of the genus Bacillus.

\section{Collection of air from $24 \mathrm{~km}$ and above}

The balloon used in the experiment was launched on 20 January 2001 from the National Scientific Balloon Facility of the Tata Institute of Fundamental Research at Hyderabad,

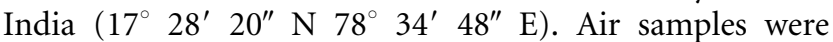
collected at various heights up to $41 \mathrm{~km}$ using a cryogenic sampler comprising a 16-probe assembly. A detailed description of the 16-probe manifold, individual probes, sterilization protocol, telemetric controls for the opening and closing of the values of the cryoprobes and the cryopump effect due to liquid neon, and all other precautions involved in the sampling process is given in Wainwright et al. (2003). Air was collected during the ascent of the balloon and, after collection of air at an altitude of $41 \mathrm{~km}$, the balloon was parachuted back to the ground. The instrument was then tracked and recovered and the probes were stored at $5{ }^{\circ} \mathrm{C}$ until further use.

\section{Detection of bacteria in air samples}

In the first procedure, two Millipore filtration units were connected in series so that air from each of the cryoprobes passed first through a $0.45 \mu \mathrm{m}$ and then through a $0.22 \mu \mathrm{m}$ Millipore filter. Each of the filters ( $47 \mathrm{~mm}$ diameter) was then cut into two halves. One half was transferred directly to a nutrient agar plate $[0.5 \%(\mathrm{w} / \mathrm{v})$ peptone, $0.3 \%(\mathrm{w} / \mathrm{v})$ beef extract, $0 \cdot 5 \%(\mathrm{w} / \mathrm{v}) \mathrm{NaCl}$ and $1.5 \%(\mathrm{w} / \mathrm{v})$ agar] and incubated at $15^{\circ} \mathrm{C}$. If colonies did not appear after up to 20 days of incubation, the filter was transferred to blood agar plates (nutrient agar plates containing $6 \%$ defibrinated goat blood) and incubated at $15{ }^{\circ} \mathrm{C}$ for another 20 days. The other half of the filter was stored at $-70^{\circ} \mathrm{C}$ for future use.
In a second procedure, attempts were made to detect bacteria that may have remained at the bottom of the cryotube or become attached to the polished walls. After all the air was expelled and filtered, the probes were injected with $100 \mathrm{ml}$ sterile $0 \cdot 1 \mathrm{M}$ phosphate buffer and agitated for $6 \mathrm{~h}$ in a shaker. The liquid was then removed using sterile tubing and a syringe and filtered sequentially through 0.45 and $0 \cdot 22 \mu \mathrm{m}$ Millipore filters (47 $\mathrm{mm}$ diameter). Each of the filters was then cut in half and each piece was incubated in LuriaBertani agar $[1 \%(\mathrm{w} / \mathrm{v})$ tryptone, $0.5 \%(\mathrm{w} / \mathrm{v})$ yeast extract, $2.5 \%(\mathrm{w} / \mathrm{v}) \mathrm{NaCl}$ and $1.5 \%(\mathrm{w} / \mathrm{v})$ agar, $\mathrm{pH} 7 \cdot 2]$ or on nutrient agar plates at $15^{\circ} \mathrm{C}$.

One half of the filter from the first isolation procedure which had been stored at $-70^{\circ} \mathrm{C}$ was brought to room temperature $\left(25^{\circ} \mathrm{C}\right)$ and three $5 \mathrm{~mm}^{2}$ pieces were excised under sterile conditions. The pieces were then gold-coated and examined at 40000 to 100000 magnification using SEM.

Air collected from 24 to $27 \mathrm{~km}$ [70 1 at normal temperature and pressure (NTP), 28 to $38 \mathrm{~km}$ (50 l at NTP) and 39 to $41 \mathrm{~km}$ (20 l at NTP)] did not yield any viable bacterial colonies on nutrient agar plates or blood agar plates even after 20 days at $15^{\circ} \mathrm{C}$. Even when incubated at $25^{\circ} \mathrm{C}$, the same plates did not show any colonies. It is possible that these filters contained bacteria that were non-culturable. However, attempts to detect bacteria on these filters by SEM also proved negative. Using the air sample collected at $41 \mathrm{~km}$, Wainwright et al. (2003) had earlier identified two bacterial species (Bacillus simplex and Staphylococcus pasteurii) and a fungus (Engyotontium album). Attempts to detect bacteria by the rRNA gene approach were also unsuccessful as the filters did not yield any DNA.

It is possible that some bacteria may have remained at the bottom of the tube or become attached to the walls of the cryotubes and thus escaped detection. To check this possibility, cryotubes devoid of air were flushed with buffer and the buffer was then spread on media plates. This procedure yielded four isolates, $24 \mathrm{~K}^{\mathrm{T}}, 28 \mathrm{~K}^{\mathrm{T}}, 41 \mathrm{KF} 2 \mathrm{a}^{\mathrm{T}}$ and $41 \mathrm{KF} 2 \mathrm{~b}^{\mathrm{T}}$, which were isolated from tubes used to collect air at 24, 28, 41 and $41 \mathrm{~km}$ altitude, respectively.

\section{Morphological, biochemical and chemotaxonomic characteristics}

Morphological, growth and biochemical studies on the viable colonies were performed using standard methods (Holding \& Collee, 1971; Smibert \& Krieg, 1994). Nutrient agar was used for growth and maintenance of the strains and for the determination of the phenotypic and chemotaxonomic characteristics as shown in Tables 1, 2 and 3 . The shape, size and motility of the strains was ascertained using a Leitz Diaplan phase-contrast microscope with an oil immersion objective $(\times 100)$. The sensitivity of the cultures to antibiotics was determined by using antibiotic discs (Himedia). Utilization of various carbon compounds as the sole carbon source was tested in mineral liquid medium 
Table 1. Phenotypic and chemotaxonomic characteristics that differentiate strains $24 \mathrm{~K}^{\top}, 28 \mathrm{~K}^{\top}, 41 \mathrm{KF}^{\top} \mathrm{a}^{\top}, B$. licheniformis MTCC $429^{\top}$ and B. sonorensis DSM $13779^{\top}$

Strains: 1 , B. aerius sp. nov. $24 \mathrm{~K}^{\mathrm{T}} ; 2$, B. aerophilus sp. nov. $28 \mathrm{~K}^{\mathrm{T}} ; 3$, B. stratosphericus sp. nov. $41 \mathrm{KF} 2 \mathrm{a}^{\mathrm{T}}$; 4 , B. licheniformis MTCC $429^{\mathrm{T}}$; 5, B. sonorensis DSM $13779^{\mathrm{T}}$. All strains show the following characteristics: aerobic growth, white colony colour on nutrient agar, motile, Gram-positive, rod-shaped cells, positive reactions for catalase, oxidase, $\beta$-galactosidase, amylase, aesculin hydrolysis, starch hydrolysis, nitrate to nitrite reduction and the Voges-Proskauer test, acid production from D-glucose, sucrose, D-fructose, D-lactose, D-galactose, D-mannose, $\mathrm{D}$-arabinose, D-xylose and mannitol and growth between $\mathrm{pH} 6$ and $\mathrm{pH} 10$ and between 20 and $37^{\circ} \mathrm{C}$. All strains exhibit growth on peptone. All strains utilize D-glucose, D-melibiose, sucrose, D-fructose, D-mannose, D-xylose, mannitol, glycerol, D-ribose, D-lactose, pyruvate, lactic acid, D-maltose, L-aspargine and L-arginine as the sole carbon source, but do not utilize L-aspartic acid. All strains are negative for the following: lipase and lysine decarboxylase activities, indole production, methyl red test, growth at $\mathrm{pH} 4$ and $\mathrm{pH} 11$ and growth in the presence of $23.4 \% \mathrm{NaCl}$. All strains are sensitive to tobramycin $(15 \mu \mathrm{g})$, lomefloxacin $(30 \mu \mathrm{g})$, roxithromycin $(30 \mu \mathrm{g})$ and streptomycin $(25 \mu \mathrm{g})$ and resistant to vancomycin $(30 \mu \mathrm{g})$ and erythromycin $(15 \mu \mathrm{g})$. +, Positive; -, negative; $\mathrm{W}$, weakly positive; R, resistant; S, sensitive. All data are from the present study.

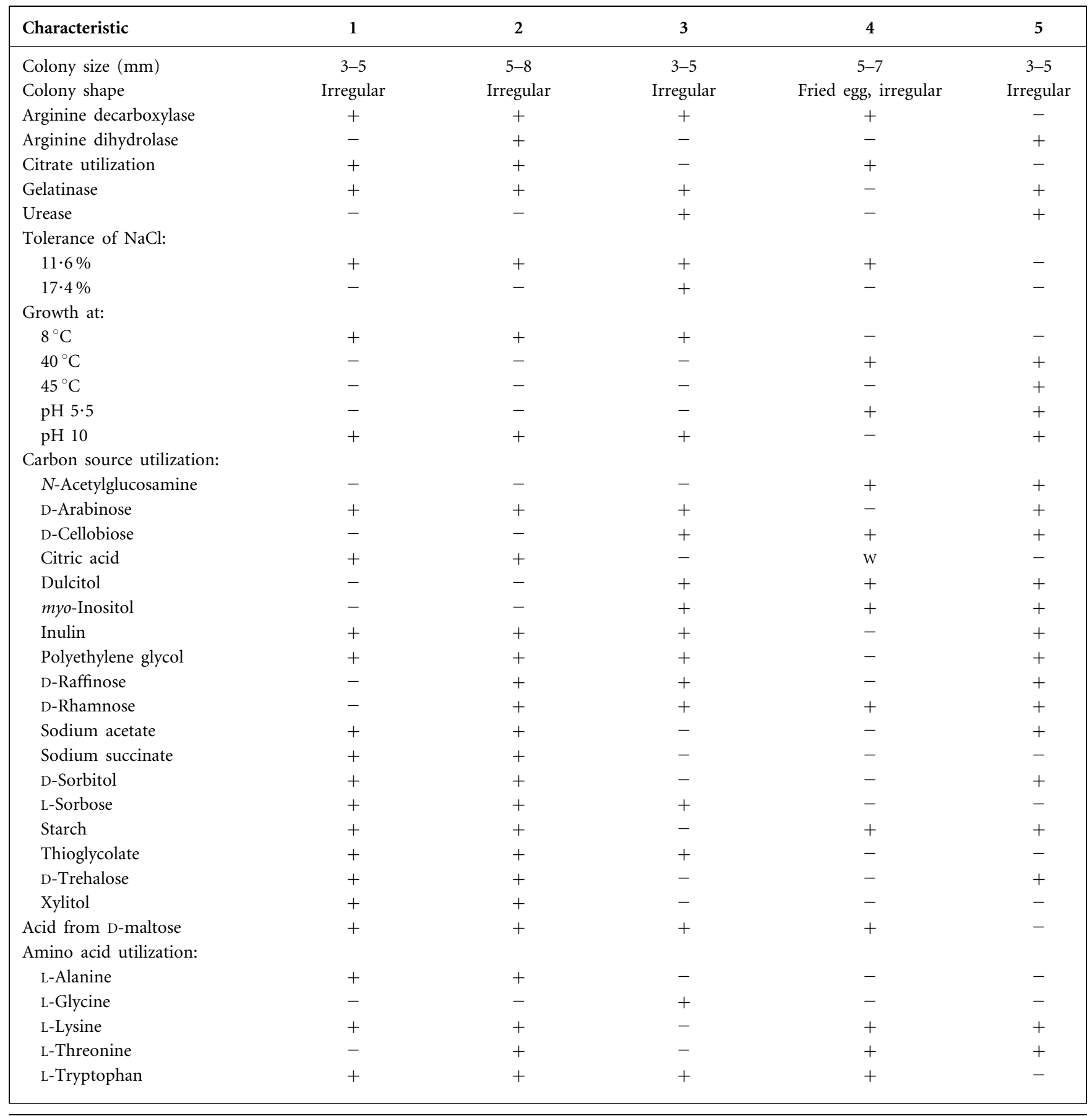


Table 1. cont.

\begin{tabular}{|c|c|c|c|c|c|}
\hline Characteristic & 1 & 2 & 3 & 4 & 5 \\
\hline \multicolumn{6}{|l|}{ Antibiotic test ( $\mu$ g per disc): } \\
\hline Amikacin (30) & $\mathrm{R}$ & $\mathrm{R}$ & $\mathrm{s}$ & $\mathrm{s}$ & $\mathrm{s}$ \\
\hline Ampicillin (25) & $\mathrm{R}$ & $\mathrm{R}$ & s & S & S \\
\hline Cefoperazone (75) & $\mathrm{R}$ & $\mathrm{R}$ & $\mathrm{R}$ & S & S \\
\hline Ciprofloxacin (30) & $\mathrm{R}$ & $\mathrm{R}$ & S & s & s \\
\hline Colistin (10) & $\mathrm{R}$ & $\mathrm{R}$ & $\mathrm{R}$ & S & $\mathrm{R}$ \\
\hline Co-trimoxazole (25) & $\mathrm{R}$ & $\mathrm{R}$ & $\mathrm{R}$ & $\mathrm{R}$ & S \\
\hline Kanamycin (30) & $\mathrm{R}$ & $\mathrm{R}$ & $\mathrm{R}$ & $\mathrm{R}$ & S \\
\hline Lincomycin (15) & $\mathrm{R}$ & s & $\mathrm{R}$ & S & S \\
\hline Novobiocin $(30)$ & s & $\mathrm{R}$ & s & s & s \\
\hline Penicillin (10) & $\mathrm{R}$ & $\mathrm{R}$ & $\mathrm{R}$ & $\mathrm{R}$ & s \\
\hline Tetracycline (30) & $\mathrm{R}$ & S & S & S & S \\
\hline Polar lipids & PE, PG, DPG & PE, PG, DPG & PE, PG, DPG & PE, DPG & PE, DPG \\
\hline DNA $\mathrm{G}+\mathrm{C}$ content $(\mathrm{mol} \%)$ & 45 & 44 & 44 & 45 & 46 \\
\hline
\end{tabular}

containing $\left(\mathrm{l}^{-1}\right) 1 \mathrm{~g}$ ammonium chloride, $0 \cdot 075 \mathrm{~g}$ dipotassium hydrogen phosphate, $1.45 \mathrm{~g}$ calcium chloride, $30.0 \mathrm{~g}$ sodium chloride, $0.075 \mathrm{~g}$ magnesium chloride, $0.75 \mathrm{~g}$ potassium chloride and $0.028 \mathrm{~g}$ ferrous sulphate, supplemented with $0 \cdot 2 \%$ of the filter-sterilized carbon source. Fatty acid methyl esters were prepared from cells grown at $25^{\circ} \mathrm{C}$ to late exponential phase in nutrient broth according to the method of Sato \& Murata (1988) and analysed as described by Kiran et al. (2004). The modified method of Bligh \& Dyer (1959) was performed to extract polar lipids and molybdenum blue reagent was used to detect lipids containing phosphate esters. The isolation of DNA and estimation of DNA G $+\mathrm{C}$ content (mol\%) was carried out according to Shivaji et al. (2005). DNA-DNA hybridization was performed by the membrane filter method of Tourova \& Antonov (1987), as described by Shivaji et al. (1992). Bacillus licheniformis MTCC $429^{\mathrm{T}}$, Bacillus pumilus MTCC $1640^{\mathrm{T}}$ and Bacillus sonorensis DSM $13779^{\mathrm{T}}$ were used as controls in studies related to biochemical tests, identification of fatty acids, polar lipids and DNA-DNA hybridization.

All four novel isolates are Gram-positive, rod-shaped, endospore-forming and catalase-positive bacteria with iso$\mathrm{C}_{15: 0}$, anteiso- $\mathrm{C}_{15: 0}$, iso- $\mathrm{C}_{16: 0}, \mathrm{C}_{16: 0}, \mathrm{C}_{16: 1} 11$ cis, iso- $\mathrm{C}_{17: 0}$ and anteiso- $\mathrm{C}_{17: 0}$ as the predominant fatty acids. The lipids present include phosphatidylethanolamine (PE), phosphatidylglycerol (PG), diphosphatidylglycerol (DPG) and two unknown phospholipids as found in B. licheniformis MTCC $429^{\mathrm{T}}$. The DNA G $+\mathrm{C}$ content of the four strains was 44-45 mol\%. All these characteristics indicate that the four novel strains are members of the genus Bacillus (see Tables 1-3).

\section{Sensitivity to UV radiation}

Cultures were grown to an $\mathrm{OD}_{660}$ of 1.0 at $30^{\circ} \mathrm{C}$ in nutrient broth and harvested at 6000 r.p.m. for $5 \mathrm{~min}$ at $5^{\circ} \mathrm{C}$ and the resulting pellet was suspended in $10 \mathrm{ml}$ phosphate buffer, $\mathrm{pH} 7 \cdot 2$. A $100 \mu \mathrm{l}$ sample of the culture was spread on nutrient agar plates. The plates were exposed to a UV lamp (UV-B, $15 \mathrm{~W} \times 4$; Sankyo Denki) with the lids open in a laminar flow hood for different time intervals. At the end of the exposure, the plates were incubated at $30{ }^{\circ} \mathrm{C}$ and the colony count was determined after 3 days. The UV intensity was determined using a UV monitor (RX003; UVI Tech). Cultures of B. licheniformis and B. pumilus type strains were used as controls in these experiments. The results indicate that the four novel strains were more UV-resistant than $B$. licheniformis MTCC $429^{\mathrm{T}}$ and B. pumilus MTCC $1640^{\mathrm{T}}$ (see Supplementary Table S1 in IJSEM Online).

\section{Phylogenetic analysis}

The 16S rRNA gene was amplified from genomic DNA, purified and sequenced as described earlier (Shivaji et al., 2000). To ascertain the phylogenetic affiliation of the novel strains, the almost-complete $16 \mathrm{~S}$ rRNA gene sequences of the four isolates were aligned with related species of the genus Bacillus using CLUSTAL W (Thompson et al., 1994). Pairwise evolutionary distances were computed using the DNADIST program with the Kimura two-parameter model, as developed by Kimura (1980). Phylogenetic trees were constructed using the UPGMA and neighbour-joining treemaking algorithms of the PHYLIP package (Felsenstein, 1993). Stability among the clades of the phylogenetic tree was assessed by taking 1000 replicates and analysing the 
Table 2. Phenotypic and chemotaxonomic differences between $B$. altitudinis sp. nov. $41 \mathrm{KF}^{2} \mathrm{~b}^{\top}$ and $B$. pumilus MTCC $1640^{\top}$

Both strains show the following characteristics: aerobic growth, white colony colour; motile, Gram-positive and rod-shaped cells; positive for catalase, oxidase, $\beta$-galactosidase and amylase activities; positive for aesculin hydrolysis; negative for reduction of nitrate to nitrite and indole production; positive for lysine decarboxylase and phenylalanine deaminase activities; do not produce gas from D-glucose; acid production from D-glucose, D-arabinose, mannitol and $\mathrm{D}$-xylose; tolerance to $2 \% \mathrm{NaCl}$; growth between $\mathrm{pH} 6$ and $\mathrm{pH} 8$; growth between 20 and $40{ }^{\circ} \mathrm{C}$; growth on peptone agar; ability to utilize sucrose, D-trehalose, starch and $\mathrm{N}$-acetylgalactosamine; inability to utilize citric acid, sodium acetate, sodium formate, sodium succinate, cellulose, L-alanine, L-threonine, L-lysine and L-arginine; sensitive to norfloxacin $(10 \mu \mathrm{g})$, penicillin $(10 \mu \mathrm{g})$, cefoperazone $(75 \mu \mathrm{g})$, cefuroxime $(30 \mu \mathrm{g})$, cephotaxime $(10 \mu \mathrm{g})$, kanamycin $(30 \mu \mathrm{g})$, co-trimoxazole $(25 \mu \mathrm{g})$, tetracycline $(30 \mu \mathrm{g})$, streptomycin $(25 \mu \mathrm{g})$ and nalidixic acid $(30 \mu \mathrm{g})$, and resistant to colistin $(10 \mu \mathrm{g}) .+$, Positive; - , negative; R, resistant; S, sensitive. All data are from the present study.

\begin{tabular}{|c|c|c|}
\hline Characteristic & $\begin{array}{c}\text { B. altitudinis } \\
\text { sp. nov. } 41 \mathrm{KF} 2 \mathrm{~b}^{\mathrm{T}}\end{array}$ & $\begin{array}{c}\text { B. pumilus } \\
\text { MTCC } 1640^{\mathrm{T}}\end{array}$ \\
\hline \multicolumn{3}{|l|}{ Growth at: } \\
\hline $\mathrm{pH} 5$ & + & - \\
\hline $8^{\circ} \mathrm{C}$ & + & - \\
\hline $45^{\circ} \mathrm{C}$ & + & - \\
\hline \multicolumn{3}{|l|}{ Hydrolysis of: } \\
\hline Casein & - & + \\
\hline Gelatin & + & - \\
\hline Starch & + & - \\
\hline Utilization of citrate & - & + \\
\hline Lipase & - & + \\
\hline Degradation of tyrosine & + & - \\
\hline Voges-Proskauer test & - & + \\
\hline \multicolumn{3}{|l|}{ Carbon source utilization: } \\
\hline $\mathrm{N}$-Acetylglucosamine & + & - \\
\hline D-Arabinose & + & - \\
\hline D-Cellobiose & + & - \\
\hline Dulcitol & + & - \\
\hline Glycerol & + & - \\
\hline myo-Inositol & + & - \\
\hline Inulin & + & - \\
\hline Polyethylene glycol & + & - \\
\hline Pyruvate & + & - \\
\hline D-Raffinose & - & + \\
\hline D-Rhamnose & + & - \\
\hline D-Sorbitol & + & - \\
\hline L-Sorbose & + & - \\
\hline Thioglycolate & + & - \\
\hline \multicolumn{3}{|l|}{ Amino acid utilization: } \\
\hline L-Glycine & + & - \\
\hline L-Tyrosine & + & - \\
\hline \multicolumn{3}{|l|}{ Antibiotics ( $\mu \mathrm{g}$ per disc): } \\
\hline Amikacin (30) & $\mathrm{R}$ & S \\
\hline Amoxycillin (30) & s & $\mathrm{R}$ \\
\hline
\end{tabular}

Table 2. cont.

\begin{tabular}{|c|c|c|}
\hline Characteristic & $\begin{array}{c}\text { B. altitudinis } \\
\text { sp. nov. } 41 \mathrm{KF} 2 \mathrm{~b}^{\mathrm{T}}\end{array}$ & $\begin{array}{c}\text { B. pumilus } \\
\text { MTCC } 1640^{\mathrm{T}}\end{array}$ \\
\hline Ampicillin (25) & $\mathrm{R}$ & S \\
\hline Ciprofloxacin (30) & $\mathrm{R}$ & S \\
\hline Lincomycin (15) & $\mathrm{R}$ & S \\
\hline Novobiocin (30) & $\mathrm{R}$ & S \\
\hline Polar lipids & PE, PG, DPG & PE, DPG \\
\hline DNA G $+\mathrm{C}$ content $(\mathrm{mol} \%)$ & 43 & 45 \\
\hline
\end{tabular}

dataset using the SEQBOOT, DNADIST, NEIGHBOR and CONSENSE programs from the PHYLIP package.

Phylogenetic analysis based on 16S rRNA gene sequence analysis indicated that strains $24 \mathrm{~K}^{\mathrm{T}}, 28 \mathrm{~K}^{\mathrm{T}}$ and $41 \mathrm{KF} 2 \mathrm{a}^{\mathrm{T}}$ are closely related to one another ( $>98 \%$ gene sequence similarity) and to B. licheniformis LMG $18422^{\mathrm{T}}(98-99 \%)$ and B. sonorensis NRRL B-23154 ${ }^{\mathrm{T}}(98 \%)$. Strain $41 \mathrm{KF} 2 \mathrm{~b}^{\mathrm{T}}$ shows $100 \%$ sequence similarity with B. pumilus TUT 1009. The neighbour-joining phylogenetic tree further confirmed that the strains are phylogenetically related to species of Bacillus and that novel isolates $24 \mathrm{~K}^{\mathrm{T}}, 28 \mathrm{~K}^{\mathrm{T}}$ and $41 \mathrm{KF} 2 \mathrm{a}^{\mathrm{T}}$ form a clade with $B$. licheniformis LMG $18422^{\mathrm{T}}$ and $B$. sonorensis NRRL B-23154 ${ }^{\mathrm{T}}$, whereas strain $41 \mathrm{KF} 2 \mathrm{~b}^{\mathrm{T}}$ forms a separate clade with B. pumilus TUT 1009 (Fig. 1). However, these strains exhibit phenotypic and chemotaxonomic differences amongst themselves and from their nearest

Table 3. Fatty acid content of strains $24 \mathrm{~K}^{\top}, 28 \mathrm{~K}^{\top}$, $41 \mathrm{KF}^{2} \mathrm{a}^{\top}$, $41 \mathrm{KF}^{2} \mathrm{~b}^{\top}$, $B$. licheniformis MTCC $429^{\top}$ and B. pumilus MTCC $1640^{\top}$

Strains: 1, B. aerius sp. nov. $24 \mathrm{~K}^{\mathrm{T}} ; 2$, B. aerophilus sp. nov. $28 \mathrm{~K}^{\mathrm{T}}$; 3, B. stratosphericus sp. nov. $41 \mathrm{KF} 2 \mathrm{a}^{\mathrm{T}} ; 4$, B. altitudinis sp. nov. $41 \mathrm{KF}_{2} \mathrm{~b}^{\mathrm{T}} ; 5$, B. licheniformis MTCC $429^{\mathrm{T}} ; 6$, B. pumilus MTCC $1640^{\mathrm{T}}$. All cultures were grown to late exponential phase in nutrient broth at $25^{\circ} \mathrm{C}$ and the cell pellets were used for fatty acid analysis. Values are percentages of total fatty acids. -, Fatty acid not detected.

\begin{tabular}{|lcccccc|}
\hline $\begin{array}{l}\text { Fatty acid } \\
\text { methyl ester }\end{array}$ & $\mathbf{1}$ & $\mathbf{2}$ & $\mathbf{3}$ & $\mathbf{4}$ & $\mathbf{5}$ & $\mathbf{6}$ \\
\hline iso-C $_{14: 0}$ & $1 \cdot 2$ & $0 \cdot 6$ & $0 \cdot 4$ & - & $0 \cdot 4$ & - \\
${\text { iso- } \mathrm{C}_{15: 0}}_{\text {anteiso-C }_{15: 0}}^{18 \cdot 6}$ & $18 \cdot 0$ & $40 \cdot 0$ & $14 \cdot 2$ & $57 \cdot 0$ & $34 \cdot 8$ & $29 \cdot 73$ \\
$\mathrm{C}_{15: 1}$ & - & $0 \cdot 9$ & - & - & - & - \\
iso-C $_{16: 0}$ & $5 \cdot 5$ & $2 \cdot 5$ & $3 \cdot 9$ & $0 \cdot 6$ & $2 \cdot 6$ & $2 \cdot 48$ \\
$\mathrm{C}_{16: 0}$ & $2 \cdot 8$ & $3 \cdot 6$ & $5 \cdot 5$ & $0 \cdot 9$ & $3 \cdot 4$ & $2 \cdot 7$ \\
$\mathrm{C}_{16: 1} 9$ cis & $5 \cdot 8$ & - & $2 \cdot 0$ & - & - & - \\
$\mathrm{C}_{16: 1} 11$ cis & $5 \cdot 6$ & $10 \cdot 1$ & $10 \cdot 4$ & $1 \cdot 8$ & $2 \cdot 1$ & $5 \cdot 35$ \\
iso-C $_{17: 0}$ & $25 \cdot 0$ & $19 \cdot 3$ & $29 \cdot 8$ & $4 \cdot 9$ & $15 \cdot 6$ & $13 \cdot 26$ \\
anteiso-C $_{17: 0}$ & $10 \cdot 1$ & $2 \cdot 0$ & $4 \cdot 8$ & $1 \cdot 1$ & $9 \cdot 2$ & - \\
$\mathrm{C}_{18: 0}$ & $1 \cdot 7$ & $1 \cdot 1$ & $1 \cdot 5$ & - & $0 \cdot 4$ & - \\
$\mathrm{C}_{18: 1}$ & $1 \cdot 3$ & $1 \cdot 1$ & $1 \cdot 5$ & - & - & - \\
\hline
\end{tabular}




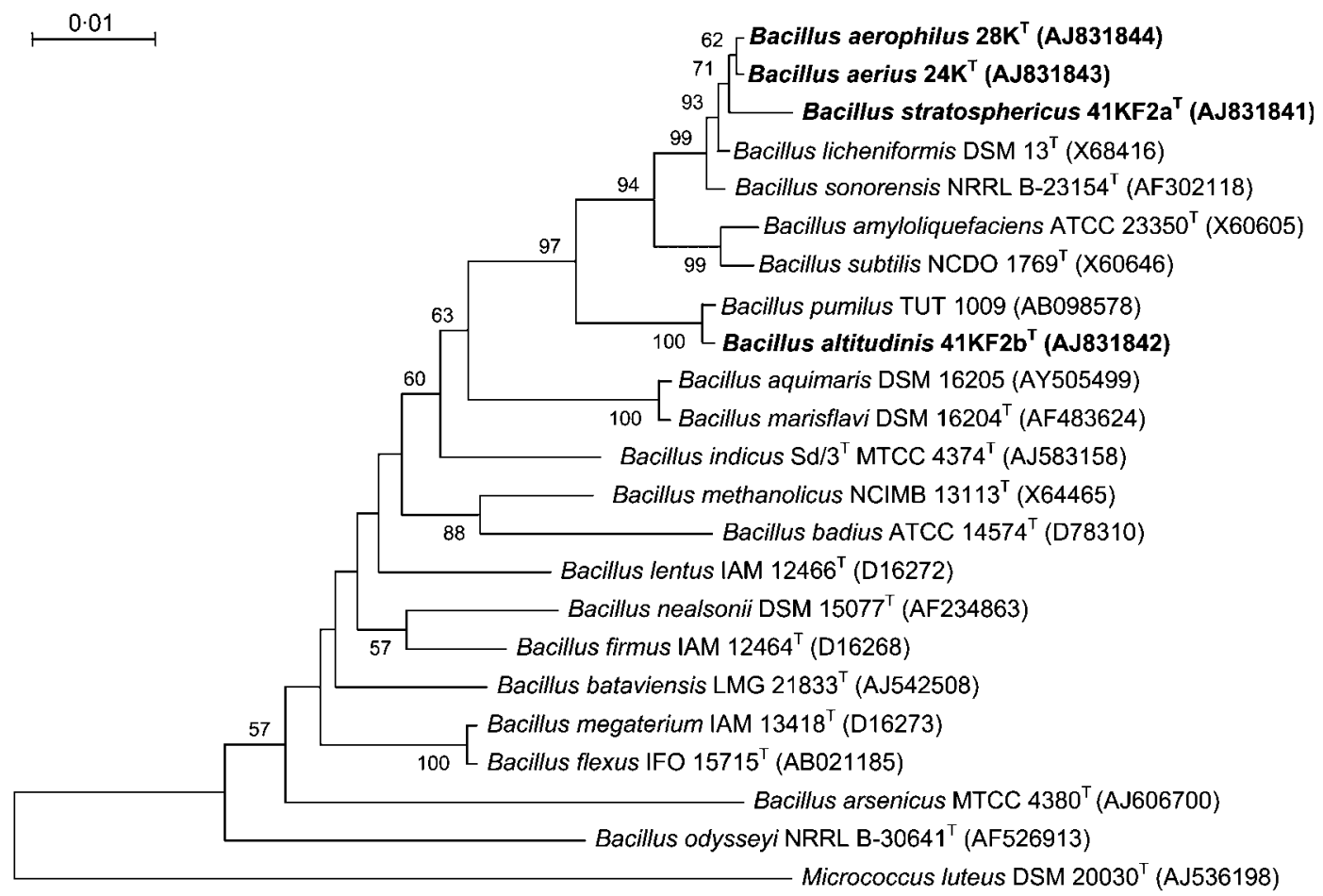

Fig. 1. Neighbour-joining tree based on $16 \mathrm{~S}$ rRNA gene sequences (1440 bases) showing the phylogenetic relationship between $B$. aerius sp. nov. $24 \mathrm{~K}^{\top}, B$. aerophilus sp. nov. $28 \mathrm{~K}^{\top}, B$. stratosphericus sp. nov. $41 \mathrm{KF}^{\mathrm{T}} \mathrm{a}^{\top}$ and $B$. altitudinis sp. nov. $41 \mathrm{KF}_{2} \mathrm{~b}^{\top}$ and closely related species of Bacillus. Micrococcus luteus DSM $20030^{\top}$ was used as an outgroup in the tree. Bootstrap values (expressed as percentages of 1000 replications) $>50 \%$ are given at nodes. Bar, 1 substitution per 100 nucleotides.

phylogenetic neighbour (Tables 1, 2 and 3 and Supplementary Table S1), thus implying that they are different. In fact, DNA-DNA hybridization studies indicate that the relatedness between strains $24 \mathrm{~K}^{\mathrm{T}}$ and $28 \mathrm{~K}^{\mathrm{T}}$ is $39 \%$, with $42 \%$ relatedness between strains $24 \mathrm{~K}^{\mathrm{T}}$ and $41 \mathrm{KF} 2 \mathrm{a}^{\mathrm{T}}$ and $10 \%$ between strains $28 \mathrm{~K}^{\mathrm{T}}$ and $41 \mathrm{KF} 2 \mathrm{a}^{\mathrm{T}}$. Further, strains $24 \mathrm{~K}^{\mathrm{T}}, 28 \mathrm{~K}^{\mathrm{T}}$ and $41 \mathrm{KF} 2 \mathrm{a}^{\mathrm{T}}$ exhibit 37,39 and $65 \%$ DNADNA relatedness with $B$. licheniformis LMG $18422^{\mathrm{T}}$ and 25 , 8 and $13 \%$ relatedness with $B$. sonorensis NRRL B-23154 ${ }^{\mathrm{T}}$, respectively. Strain $41 \mathrm{KF} 2 \mathrm{~b}^{\mathrm{T}}$ exhibits $55 \%$ relatedness with B. pumilus TUT 1009. Thus, based on phenotypic and chemotaxonomic (lipid and fatty acid content) differences and $<70 \%$ relatedness at the DNA-DNA level, it is proposed that strains $24 \mathrm{~K}^{\mathrm{T}}, 28 \mathrm{~K}^{\mathrm{T}}, 41 \mathrm{KF} 2 \mathrm{a}^{\mathrm{T}}$ and $41 \mathrm{KF} 2 \mathrm{~b}^{\mathrm{T}}$ represent novel species and the names Bacillus aerius sp. nov., Bacillus aerophilus sp. nov., Bacillus stratosphericus sp. nov. and Bacillus altitudinis sp. nov. respectively, are proposed.

It is interesting to speculate on the possible origin of the four novel strains identified in this study. It is possible that the four novel strains are not contaminants carried from the Earth during the balloon flight or subsequent processing of the samples. By theoretical analysis of some 3.5 million organic compounds listed in Beilstein (http://www.beilstein. com), it has recently been argued (Morowitz et al., 2000) that, if carbon- and water-based life exists anywhere else, it would have the same basic pattern of intermediary metabolism that is found in living organisms on our planet. This would make it likely that prokaryotes that may have evolved elsewhere would be similar to those found here. It is therefore tempting to speculate that strains $24 \mathrm{~K}^{\mathrm{T}}, 28 \mathrm{~K}^{\mathrm{T}}$, $41 \mathrm{KF} 2 \mathrm{a}^{\mathrm{T}}$ and $41 \mathrm{KF} 2 \mathrm{~b}^{\mathrm{T}}$ are a gift to us from space, but other explanations, such as their terrestrial origin, cannot be ruled out.

The possible Earth origin of micro-organisms in extraterrestrial samples is further supported by data indicating routine meteorite exchanges between Earth and Mars (Gladman et al., 1996), the probability that bacterial spores could survive interplanetary transfer (Mileikowsky et al., 2000; Nicholson et al., 2000) and the likelihood that certain bacterial species are resistant to current sterilization protocols and are therefore carried by spacecraft from Earth. In fact, with this in mind, robotic spacecraft used to search for life on other planets are assembled in clean rooms with controlled air circulation and are sterilized using a number of methods, including hydrogen peroxide vapour and UV radiation (Chung et al., 2000). Despite these stringent sterilization protocols, a number of microbial species have 
been isolated from the NASA Jet Propulsion Laboratories Spacecraft Assembly Facility (JPL-SAF) (Venkateswaran et al., 2001) and from the Mars Odyssey spacecraft and its encapsulation facility (La Duc et al., 2003). The predominant isolates belonged to the spore-forming genus Bacillus and were closely related to B. pumilus (Link et al., 2004; Venkateswaran et al., 2001). Many of these strains of $B$. pumilus were significantly more UV-resistant than previously isolated strains and one of these strains exhibited the highest degree of UV-resistance when compared with all known Bacillus species (Link et al., 2004). These studies also led to the discovery of two novel species of Bacillus, Bacillus nealsonii, isolated from a spacecraft assembly facility, and Bacillus odysseyi, which were resistant to UV radiation (La Duc et al., 2004; Venkateswaran et al., 2003). Therefore, the possibility that the four novel strains, $24 \mathrm{~K}^{\mathrm{T}}, 28 \mathrm{~K}^{\mathrm{T}}, 41 \mathrm{KF} 2 \mathrm{a}^{\mathrm{T}}$ and $41 \mathrm{KF} 2 \mathrm{~b}^{\mathrm{T}}$, which are endospore-forming Bacillus species, escaped the stringent sterilization protocols (which included acetone wash, ethanol rinse, autoclaving and baking at $150{ }^{\circ} \mathrm{C}$ for $1 \mathrm{~h}$ ) used to sterilize the cryotubes cannot be ruled out. The greater UV-resistance observed in the four novel strains compared with strains of $B$. licheniformis and $B$. pumilus (Supplementary Table S1 in IJSEM Online) may be related to their isolation from altitudes $>24 \mathrm{~km}$ where UV radiation is likely to be more intense than on the ground. Strains $24 \mathrm{~K}^{\mathrm{T}}, 28 \mathrm{~K}^{\mathrm{T}}, 41 \mathrm{KF} 2 \mathrm{a}^{\mathrm{T}}$ and $41 \mathrm{KF} 2 \mathrm{~b}^{\mathrm{T}}$, which differ from their nearest phylogenetic neighbours $B$. licheniformis, $B$. sonorensis and B. pumilus, are proposed as representatives of four novel species of Bacillus.

\section{Description of Bacillus aerius sp. nov.}

Bacillus aerius (ae' ri.us. L. masc. adj. aerius pertaining to the air, aerial).

Colonies on nutrient agar are white, irregular, raised and $3-5 \mathrm{~mm}$ in diameter. Growth occurs at $8-37^{\circ} \mathrm{C}$, but not at $40{ }^{\circ} \mathrm{C}$. Growth occurs between $\mathrm{pH} 6$ and 10 , but not at $\mathrm{pH} 4$ or $\mathrm{pH} 11$. Tolerates up to $11 \cdot 6 \% \mathrm{NaCl}$. Resistant to UV radiation. Grows on peptone. Positive for arginine decarboxylase activity and negative for arginine dihydrolase activity. Produces acid from a number of substrates and utilizes a number of sugars, amino acids and other carbon compounds as sole carbon sources (Table 1). The type strain is sensitive to tobramycin $(15 \mu \mathrm{g})$, lomefloxacin $(30 \mu \mathrm{g})$, roxithromycin $(30 \mu \mathrm{g})$, streptomycin $(25 \mu \mathrm{g})$ and novobiocin $(30 \mu \mathrm{g})$ and resistant to penicillin $(10 \mu \mathrm{g})$, nalidixic acid $(30 \mu \mathrm{g})$, ampicillin $(25 \mu \mathrm{g})$, kanamycin $(30 \mu \mathrm{g})$, colistin $(10 \mu \mathrm{g})$, novobiocin $(30 \mu \mathrm{g})$, co-trimoxazole $(25 \mu \mathrm{g})$, vancomycin $(30 \mu \mathrm{g})$, tetracycline $(30 \mu \mathrm{g})$, chloramphenicol $(30 \mu \mathrm{g})$, erythromycin $(15 \mu \mathrm{g})$, norfloxacin $(10 \mu \mathrm{g})$, ciprofloxacin $(30 \mu \mathrm{g})$, lincomycin $(15 \mu \mathrm{g})$, cefoperazone $(75 \mu \mathrm{g})$, amikacin $(30 \mu \mathrm{g})$, cefuroxime $(30 \mu \mathrm{g})$ and amoxycillin $(30 \mu \mathrm{g})$. The major fatty acids are iso- $\mathrm{C}_{17: 0}$, iso- $\mathrm{C}_{15: 0}$, anteiso- $\mathrm{C}_{15: 0}$, anteiso- $\mathrm{C}_{17: 0}$, iso $\mathrm{C}_{16: 0}, \mathrm{C}_{16: 1} 9$ cis and $\mathrm{C}_{16: 1}$ 11 cis (Table 3). The lipids present are PE, PG, DPG and two unknown phospholipids. The DNA G $+\mathrm{C}$ content is $45 \mathrm{~mol} \%$.
The type strain, $24 \mathrm{~K}^{\mathrm{T}}\left(=\right.$ MTCC $\left.7303^{\mathrm{T}}=\mathrm{JCM} 13348^{\mathrm{T}}\right)$, was isolated from cryogenic tubes used for collecting air samples from high altitudes.

\section{Description of Bacillus aerophilus sp. nov.}

Bacillus aerophilus (ae.ro.phi'lus. Gr. n. aêr air; Gr. adj. philos loving; N.L. masc. adj. aerophilus air-loving).

Colonies on nutrient agar are white, irregular, raised and $5-8 \mathrm{~mm}$ in diameter. Growth occurs at $8-37^{\circ} \mathrm{C}$, but not at $40^{\circ} \mathrm{C}$. Growth occurs between $\mathrm{pH} 6$ and $\mathrm{pH} 10$, but not at pH 5 or pH 11. Tolerates up to $11 \cdot 6 \% \mathrm{NaCl}$. Resistant to UV radiation. Grows on peptone. Positive for arginine decarboxylase and arginine dihydrolase activities. Produces acid from a number of substrates and utilizes a number of sugars, amino acids and other carbon compounds as sole carbon sources (Table 1). The type strain is sensitive to tobramycin $(15 \mu \mathrm{g})$, lomefloxacin $(30 \mu \mathrm{g})$, roxithromycin $(30 \mu \mathrm{g})$, lincomycin $(15 \mu \mathrm{g})$, tetracycline $(30 \mu \mathrm{g})$ and streptomycin $(25 \mu \mathrm{g})$ and resistant to amikacin $(30 \mu \mathrm{g})$, ampicillin $(25 \mu \mathrm{g})$, nalidixic acid $(30 \mu \mathrm{g})$, penicillin $(10 \mu \mathrm{g})$, kanamycin $(30 \mu \mathrm{g})$, co-trimoxazole $(25 \mu \mathrm{g})$, vancomycin $(30 \mu \mathrm{g})$, chloramphenicol $(30 \mu \mathrm{g})$, erythromycin $(15 \mu \mathrm{g})$, norfloxacin $(10 \mu \mathrm{g})$, colistin $(10 \mu \mathrm{g})$, novobiocin $(30 \mu \mathrm{g})$, ciprofloxacin $(30 \mu \mathrm{g})$ cefoperazone $(75 \mu \mathrm{g})$, cefuroxime $(30 \mu \mathrm{g})$ and amoxycillin $(30 \mu \mathrm{g})$. The major fatty acids are anteiso- $\mathrm{C}_{15: 0}$, iso- $\mathrm{C}_{17: 0}$, iso- $\mathrm{C}_{15: 0}$ and $\mathrm{C}_{16: 1} 11$ cis (Table 3). The lipids present are PE, PG, DPG and two unknown phospholipids. The DNA $\mathrm{G}+\mathrm{C}$ content is $44 \mathrm{~mol} \%$.

The type strain, $28 \mathrm{~K}^{\mathrm{T}}\left(=\right.$ MTCC $\left.7304^{\mathrm{T}}=\mathrm{JCM} 13347^{\mathrm{T}}\right)$, was isolated from cryogenic tubes used for collecting air samples from high altitudes.

\section{Description of Bacillus stratosphericus sp. nov.}

Bacillus stratosphericus (stra.to.sphe.ri'cus. N.L. fem. n. stratosphera stratosphere; L. suff. -icus adjectival suffix used with the sense of belonging to; N.L. masc. adj. stratosphericus belonging to the stratosphere).

Colonies on nutrient agar are white, irregular, raised and $3-5 \mathrm{~mm}$ in diameter. Growth occurs between 8 and $37^{\circ} \mathrm{C}$, but not at $40^{\circ} \mathrm{C}$. Growth occurs between $\mathrm{pH} 6$ and pH 10, but not at $\mathrm{pH} 5$ or $\mathrm{pH} 11$. Tolerates up to $17 \cdot 4 \% \mathrm{NaCl}$. Resistant to UV radiation. Shows growth on peptone. Positive for arginine decarboxylase activity and negative for arginine dihydrolase activity. Produces acid from a number of substrates and utilizes a number of sugars, amino acids and other carbon compounds as sole carbon sources (Table 1). Sensitive to tobramycin $(15 \mu \mathrm{g})$, lomefloxacin $(30 \mu \mathrm{g})$, roxithromycin $(30 \mu \mathrm{g})$, amikacin $(30 \mu \mathrm{g})$, ciprofloxacin $(30 \mu \mathrm{g})$, streptomycin $(25 \mu \mathrm{g})$, novobiocin $(30 \mu \mathrm{g})$, ampicillin $(25 \mu \mathrm{g})$ and nalidixic acid $(30 \mu \mathrm{g})$ and resistant to penicillin $(10 \mu \mathrm{g})$, kanamycin $(30 \mu \mathrm{g})$, co-trimoxazole $(25 \mu \mathrm{g})$, vancomycin $(30 \mu \mathrm{g})$, chloramphenicol $(30 \mu \mathrm{g})$, erythromycin $(15 \mu \mathrm{g})$, norfloxacin $(10 \mu \mathrm{g})$, cefoperazone $(75 \mu \mathrm{g})$, cefuroxime $(30 \mu \mathrm{g})$, lincomycin $(15 \mu \mathrm{g})$, colistin 
$(10 \mu \mathrm{g})$ and amoxycillin $(30 \mu \mathrm{g})$. The major fatty acids are iso- $\mathrm{C}_{17: 0}$, anteiso- $\mathrm{C}_{15: 0}$, iso- $\mathrm{C}_{15: 0}, \mathrm{C}_{16: 1} 11$ cis and $\mathrm{C}_{16: 0}$ (Table 3). The lipids present are PE, PG, DPG and two unknown phospholipids. The DNA $\mathrm{G}+\mathrm{C}$ content is $44 \mathrm{~mol} \%$.

The type strain, $41 \mathrm{KF} 2 \mathrm{a}^{\mathrm{T}}\left(=\right.$ MTCC $\left.7305^{\mathrm{T}}=\mathrm{JCM} 13349^{\mathrm{T}}\right)$, was isolated from cryogenic tubes used for collecting air samples from high altitudes.

\section{Description of Bacillus altitudinis sp. nov.}

Bacillus altitudinis (al.ti'tu.di.nis. L. fem. n. altitudo altitude; L. fem. gen. n. altitudinis of altitude).

Colonies on nutrient agar are white, convex with a regular margin and $2-3 \mathrm{~mm}$ in diameter. Growth occurs between 8 and $45^{\circ} \mathrm{C}$ and at $\mathrm{pH} 5-8$. Tolerates up to $2 \% \mathrm{NaCl}$. Degrades tyrosine, but tests negative for casein hydrolysis, urease and phenylalanine deaminase activities, reduction of nitrate to nitrite, utilization of citrate and the VogesProskauer test. Produces acid from mannitol. Utilizes D-trehalose, starch, $\mathrm{N}$-acetylglucosamine, D-rhamnose, D-cellobiose, D-sorbitol, dulcitol, myo-inositol, $\mathrm{N}$-acetylgalactosamine, L-glycine, L-threonine and L-lysine as sole carbon sources. Sensitive to norfloxacin $(10 \mu \mathrm{g})$, penicillin $(10 \mu \mathrm{g})$, cefoperazone $(75 \mu \mathrm{g})$, cefuroxime $(30 \mu \mathrm{g})$, kanamycin $(30 \mu \mathrm{g})$, co-trimoxazole $(25 \mu \mathrm{g})$, tetracycline $(30 \mu \mathrm{g})$, nalidixic acid $(30 \mu \mathrm{g})$ and amoxycillin $(30 \mu \mathrm{g})$, but resistant to amikacin $(30 \mu \mathrm{g})$, ciprofloxacin $(30 \mu \mathrm{g})$, lincomycin $(15 \mu \mathrm{g})$, novobiocin $(30 \mu \mathrm{g})$ and ampicillin $(25 \mu \mathrm{g})$. Major fatty acids are iso- $\mathrm{C}_{15: 0}$, anteiso- $\mathrm{C}_{15: 0}$ and iso- $\mathrm{C}_{17: 0}$ (Table 3). The lipids present are PE, PG, DPG and two unknown phospholipids. The DNA $\mathrm{G}+\mathrm{C}$ content is $43 \mathrm{~mol} \%$.

The type strain, $41 \mathrm{KF} 2 \mathrm{~b}^{\mathrm{T}}\left(=\right.$ MTCC $\left.7306^{\mathrm{T}}=\mathrm{JCM} 13350^{\mathrm{T}}\right)$, was isolated from cryogenic tubes used for collecting air samples from high altitudes.

\section{Acknowledgements}

Our thanks are due to Indian Space Research Organization, Department of Space, Government of India for financial assistance. The authors would also like to thank Dr Rajaratnam of ISRO for his involvement in the project.

\section{References}

Bligh, E. G. \& Dyer, W. J. (1959). A rapid method of total lipid extraction and purification. Can J Biochem Physiol 37, 911-917.

Bruch, C. W. (1967). Microbes in the upper atmosphere and beyond. In Airborne Microbes (Society for General Microbiology Symposium no. 17), pp. 345-373. Edited by P. H. Gregory \& J. L. Monteith. Cambridge: Cambridge University Press.

Chung, S., Echeverria, C., Kern, R. \& Venkateswaran, K. (2000). Low-temperature $\mathrm{H}_{2} \mathrm{O}_{2}$ gas plasma - a sterilization process useful in space exploration technology. In Abstracts of the 100th General Meeting of the American Society for Microbiology, 2000. Washington, DC: American Society for Microbiology.
Felsenstein, J. (1993). PHYLIP (phylogeny inference package), version 3.5c. Distributed by the author. Department of Genome Sciences, University of Washington, Seattle, USA.

Gladman, B. J., Burns, J. A., Duncan, M., Lee, P. \& Levinson, H. F. (1996). The exchange of impact ejecta between terrestrial planets. Science 271, 1387-1392.

Greene, V. W., Pederson, P. D., Lundgren, D. A. \& Hagberg, C. A. (1964). Microbiological exploration of stratosphere: Results of six experimental flights. In Proceedings of the Atmospheric Biology Conference, University of Minnesota, 13-15 April, 1964, pp. 199-211. Washington, DC: National Aeronautics and Space Administration.

Harris, M. J., Wickramasinghe, N. C., Lloyd, D. \& 7 other authors (2001). The detection of living cells in stratospheric samples. In Instruments, Methods and Missions for Astrobiology IV, Proceedings of the SPIE Conference 2001, vol. 4495, pp. 192-198. Edited by R. B. Hoover, G. V. Levin, Paepe, R. R. \& A. Y. Rozanov. Bellingham, WA: SPIE.

Holding, A. J. \& Collee, J. G. (1971). Routine biochemical tests. Methods Microbiol 6A, 2-32.

Hoyle, F. \& Wickramasinghe, N. C. (1986). The case for life as a cosmic phenomenon. Nature 322, 509-511.

Hoyle, F. \& Wickramasinghe, N. C. (1993). Our Place in the Cosmos. London: J. M. Dent.

Hoyle, F. \& Wickramasinghe, N. C. (1999). Astronomical Origins Of Life: Steps Towards Panspermia. Dordrecht: Kluwer.

Kimura, M. (1980). A simple method for estimating evolutionary rates of base substitutions through comparative studies of nucleotide sequences. J Mol Evol 16, 111-120.

Kiran, M. D., Prakash, J. S. S., Annapoorni, S., Dube, S., Kusano, T., Okuyama, H., Murata, N. \& Shivaji, S. (2004). Psychrophilic Pseudomonas syringae requires trans-monounsaturated fatty acid for growth at higher temperature. Extremophiles 8, 401-410.

La Duc, M. T., Nicholson, W., Kern, R. \& Venkateswaran, K. (2003). Microbial characterization of the Mars Odyssey spacecraft and its encapsulation facility. Environ Microbiol 5, 977-985.

La Duc, M. T., Satomi, M. \& Venkateswaran, K. (2004). Bacillus odysseyi sp. nov., a round spore-forming bacillus isolated from the Mars Odyssey spacecraft. Int J Syst Evol Microbiol 54, 195-201.

Link, L., Sawyer, J., Venkateswaran, K. \& Nicholson, W. (2004). Extreme spore UV resistance of Bacillus pumilus isolates obtained from an ultraclean spacecraft assembly facility. Microb Ecol 47, 159-163.

Love, S. G. \& Brownlee, D. E. (1993). A direct measurement of the terrestrial mass accretion rate of cosmic dust. Science 262, 550-553.

Lysenko, S. V. (1979). Microorganisms of the upper layers of the atmosphere. Mikrobiologiia 48, 1066-1074 (in Russian).

Mileikowsky, C., Cucinotta, F. A., Wilson, J. W. \& 7 other authors (2000). Natural transfer of viable microbes in space. Icarus 145, 391-427.

Morowitz, H. J., Kostelnik, J. D., Yang, J. \& Cody, G. D. (2000). The origin of intermediary metabolism. Proc Natl Acad Sci U S A 97, 7704-7708.

Nicholson, W. L., Munakata, N., Horneck, G., Melosh, H. J. \& Setlow, P. (2000). Resistance of Bacillus endospores to extreme terrestrial and extraterrestrial environments. Microbiol Mol Biol Rev 64, 548-572.

Rogers, L. A. \& Meier, F. C. (1936). In Technical Paper, US Army Air Corps Stratosphere Flight of 1935 in Balloon Explorer II, pp. 146-151. Washington, DC: National Geographic Society.

Sato, N. S. \& Murata, N. (1988). Membrane lipids. Methods Enzymol $167,251-259$. 
Shivaji, S., Ray, M. K., Rao, N. S., Saisree, L., Jagannadham, M. V., Kumar, G. S., Reddy, G. S. N. \& Bhargava, P. M. (1992). Sphingobacterium antarcticus sp. nov., a psychrotrophic bacterium from the soils of Schirmacher Oasis, Antarctica. Int J Syst Bacteriol 42, 102-116.

Shivaji, S., Bhanu, N. V. \& Aggarwal, R. K. (2000). Identification of Yersinia pestis as the causative organism of plague in India as determined by $16 \mathrm{~S}$ rDNA sequencing and RAPD-based genomic fingerprinting. FEMS Microbiol Lett 189, 247-252.

Shivaji, S., Chaturvedi, P., Reddy, G. S. N. \& Suresh, K. (2005). Pedobacter himalayensis sp. nov., from the Hamta glacier located in the Himalayan mountain ranges of India. Int J Syst Evol Microbiol 55, 1083-1088.

Smibert, R. M. \& Krieg, N. R. (1994). Phenotypic characterization. In Methods for General and Molecular Bacteriology, pp. 607-654. Edited by P. Gerhardt, R. G. E. Murray, W. A. Wood \& N. R. Krieg. Washington, DC: American Society for Microbiology.
Thompson, J. D., Higgins, D. G. \& Gibson, T. J. (1994). CLUSTAL W: improving the sensitivity of progressive multiple sequence alignment through sequence weighting, position-specific gap penalties and weight matrix choice. Nucleic Acids Res 22, 4673-4680.

Tourova, T. P. \& Antonov, A. S. (1987). Identification of microorganisms by rapid DNA-DNA hybridization. Methods Microbiol 19, 333-355.

Venkateswaran, K., Satomi, M., Chung, S., Kern, R., Koukol, R., Basic, C. \& White, D. (2001). Molecular microbial diversity of a spacecraft assembly facility. Syst Appl Microbiol 24, 311-320.

Venkateswaran, K., Kempf, M., Chen, F., Satomi, M., Nicholson, W. \& Kern, R. (2003). Bacillus nealsonii sp. nov., isolated from a spacecraft-assembly facility, whose spores are $\gamma$-radiation resistant. Int J Syst Evol Microbiol 53, 165-172.

Wainwright, M., Wickramasinghe, N. C., Narlikar, J. V. \& Rajaratnam, P. (2003). Microorganisms cultured from stratospheric air samples obtained at $41 \mathrm{~km}$. FEMS Microbiol Lett 218, 161-165. 